\title{
FUNDAMENTAL RIGHTS IN THE \\ UNITED KINGDOM: THE LAW AND THE BRITISH CONSTITUTION*
}

\author{
ANTHONY LESTER $\dagger$ \\ I. INTRODUCTION
}

I am honoured to have been invited to give this lecture and more grateful than words can express. It is a daunting invitation, especially when one recalls the demanding standards of the Owen J. Roberts Memorial Lectureship and the distinguished character of my predecessors. And it is a particular privilege for an Englishman-who is not a judge, a statesman, or a professor, but a practitioner at the English Bar-to have been asked to lecture in this historic birthplace of the Declaration of Independence during the year of the Bicentennial celebrations.

I believe that Mr. Justice Roberts would have been interested by my theme. In his judicial capacity, he was a member of a divided Court that was called upon to reconcile the constitutional guarantees of personal liberty both with the proper allocation of power between the federal government and the states of the Union, and with the imperatives of a great modern industrial nation. His judicial experience would surely have made him interested in the way in which we, in the United Kingdom; have wrestled with analogous constitutional and legal problems, without a written constitution or a binding Bill of Rights. And his work for international federation and Atlantic union, after his retirement from the Supreme Court, indicates that he would have been fascinated by the constitutional and legal consequences of the creation of a European Community, inspired by the making of the United States.

* This Article was delivered originally as the Owen J. Roberts Memorial Lecture, October 18, 1976, under the auspices of the Pennsylvania Chapter of the Order of the Coif, the Law Alumni Society, and the University of Pennsylvania Law School.

$\dagger$ Queen's Counsel. B.A. 1960, Cambridge University; LL.M. 1962, Harvard University. Mr. Lester was the Special Adviser to the Secretary of State for the Home Department 1974-1976. 


\section{Parliamentary Sovereignty and the ROLE OF THE JUDICIARY}

I shall begin by describing the peculiar and distinctive features of the British constitution. The cornerstone of our system is the absolute and unfettered sovereignty of the national legislature. Parliament has the right to make or unmake any law whatsoever, and no person or body has the right to override or set aside the legislation of Parliament. We make no distinction between laws that are not fundamental or constitutional and laws that are fundamental or constitutional, and there is no supreme law against which to test the validity of other laws.

The doctrine of Parliamentary sovereignty was formulated in clear and uncompromising terms by Professor A. V. Dicey, in 1885, in his celebrated Introduction to the Study of the Law of the Constitution. He illustrated the doctrine in this way:

There are indeed important statutes, such as the Act embodying the Treaty of Union with Scotland, with which it would be political madness to tamper gratuitously; there are utterly unimportant statutes, such, for example, as the Dentists Act, 1878, which may be repealed or modified at the pleasure or caprice of Parliament; but neither the Act of Union with Scotland nor the Dentists Act ... has more claim than the other to be considered a supreme law. Each embodies the will of the sovereign legislative power; each can be legally altered or repealed by Parliament; neither tests the validity of the other. Should the Dentists Act ... unfortunately contravene the terms of the Act of Union, the Act of Union would be pro tanto repealed, but no judge would dream of maintaining that the Dentists Act ... was thereby rendered invalid or unconstitutional. The one fundamental dogma of English constitutional law is the absolute legislative sovereignty or despotism of the King in Parliament. ${ }^{1}$

As Dicey's example indicates, one important consequence of the principle of the omnicompetence and undisputed supremacy of the central government in Parliament is the secondary nature of Dicey's other constitutional principle: the rule of supremacy of the law. During the seventeenth century, the judges struggled

${ }^{1}$ A.V. Dicey, An Introduction to the Study of The Constiturion 145 (10th ed. 1959). The Scottish judicial view is rather different. See note 28 infra. 
not only for independence from the executive but also for the right to withhold effect from laws that they regarded as unconscionable or contrary to a higher, fundamental, and immutable natural law. The judges won the struggle for independence against the Crown's claim to rule by prerogative, but the price paid by the common lawyers for their alliance with Parliament against the divine right of kings was that the common law could be changed by Parliament as it pleased. ${ }^{2}$ The glorious, bloodless revolution was won by Parliament; and although the Bill of Rights of 1688 and the Act of Settlement of 1700 recognised some important personal rights and liberties, the terms of the constitutional settlement were mainly concerned with the rights and liberties of Parliament itself. The alliance of Parliament and the common lawyers ensured that in the long run the supremacy of the law would mean the supremacy of Parliament ${ }^{3}$ or, more realistically, the supremacy of the central government in Parliament.

The principal safeguards against the abuse of power by the government in Parliament are therefore not legally enforceable: they are constitutional understandings, conventions, or principles of good administration, the observance of which depends upon the sense of fair play of Ministers and their civil servants; the vigilance of the Opposition and individual Members of Parliament; the influence of the press, broadcasting, and public opinion; and the periodic opportunity of changing the government through free and secret elections.

I do not mean to suggest that the constitutional role of the independent judiciary is unimportant in interpreting and applying the common law and statute law. Should a Minister or a public body exceed the powers conferred by statute, or misinterpret the intention of Parliament as expressed in a statute, or transgress a rule of the common law, it is the vital function of the courts to intervene and to provide redress. To their credit, under the leadership of the late Lord Reid and Lord Denning, the House of Lords and the Court of Appeal have been astute in the past few years in restraining the misuse of the powers of the state. The courts have prevented Ministers from exceeding or misinterpreting their statutory powers; ${ }^{4}$ they have compelled the

\footnotetext{
${ }^{2}$ Wade, Introduction to A.V. Dicex, supra note 1 , at c.

${ }^{3} I d$. ci.

4See, e.g., Padfield v. Minister of Agric., Fisheries \& Food, [1968] A.C. 997; Con-
} 
disclosure of documents for which executive privilege had been claimed unreasonably in the course of legal proceedings; ${ }^{5}$ and they have widened the common law rules of natural justice to apply more flexible standards of fairness both to public bodies ${ }^{6}$ and also to private associations exercising monopolistic powers. ${ }^{7}$ These decisions represent an unprecedented extension of the judicial review of administrative action in the United Kingdom.

But such recent and desirable changes in judicial attitudes should not obscure the central fact that the constitutional role of the judges in protecting human rights remains narrowly circumscribed by their subordinate position in relation to the legislative sovereignty of Parliament, by the absence of coherent and comprehensive constitutional and administrative standards, and by constraints that have been imposed by the judges themselves. Most British politicians, civil servants, and lawyers-and many ordinary people-welcome the narrowness of the judicial function. They share a public philosophy that may be summarised roughly in the following way.

The task of lawmaking is the exclusive province of the elected representatives of the people, whether in the central government, which is directly accountable to Parliament, or in regional and local government, which is accountable to the local electors. It would be undemocratic for the nonelected judiciary to act as lawmakers. It would also be inappropriate because judges are ill-equipped by their training and professional experience and by the very nature of the judicial process itself, to perform this difficult task. Moreover, it would be undesirable for judges to become involved in controversial issues of policy, because their decisions would be less certain and predictable and would make them more vulnerable to criticism in the political arena.

According to this view, the surest and most effective safeguards of human rights and freedoms are not the rigid legalism and paper guarantees of written constitutions and Bills of Rights but the benevolent exercise of discretion by public

greve v. Home Office, [1976] Q.B. 629 (C.A.); Secretary of State for Educ. \& Science v. Tameside Metropolitan Borough Council, [1976] 3 All E.R. 665.

${ }^{5}$ See, e.g., Conway v. Rimmer, [1968] A.C. 910.

${ }^{6}$ See, e.g., Ridge v. Baldwin, [1964] A.C. 40 (1963); Regina v. Gaming Bd., [1970] 2 Q.B. 417 (C.A.); In re H.K. [1967] 2 Q.B. 617.

${ }^{7}$ See, e.g., Edwards v. Society of Graphical \& Allied Trades, [1970] 3 W.L.R. 713 (C.A.); Breen v. Amalgamated Eng'r Union, [1971] 2 Q.B. 175 (C.A.); Nagle v. Feilden, [1966] 2 Q.B. 633 (C.A.). 
officials, who are accountable through their political masters to the legislature and the people, accompanied by the efficiency and careful scrutiny of the legislative process. Any dilution of the sovereignty of the central government in Parliament-for example, by the creation of a federal structure with formal checks and balances and a supreme constitutional court that administers the supreme law of the land-would be a recipe for weak and ineffective government as well as for a surfeit of litigation. Any dilution of Parliamentary sovereignty would also threaten the political and economic unity of the United Kingdom as a whole. For these reasons the role of the judiciary is regarded as being rightly confined to the interpretation and application of the common law and statute law. In seeking to ascertain the intention of Parliament, the judges should subject the language of a statute to careful textual analysis, concerning themselves with bare questions of law and not with the ethical, social, and economic implications of their decisions. If either this process of textual analysis of the words of a statute or the courts' interpretation of the common law has undesirable consequences, the matter must be corrected by the legislature and not by the courts. $^{8}$

Some of you may feel that such a public philosophy gives you particular cause to rejoice in the Bicentennial celebrations. But one should not dismiss the virtue of the British system too readily. Human rights may not be "fundamental" in a constitutional sense, but it is arguable that they are as well protected and that the spirit of liberty is as strong in the United Kingdom as in those democratic societies that have written constitutions, Bills of Rights, and comprehensive systemis of administrative law.

Measured by the volume of legislation, the British legislative process is highly efficient, ${ }^{9}$ and recent reforms have increased

${ }^{8}$ During the second half of the nineteenth century, this approach led the House of Lords to invent the bizarre rule that their previous decisions had the force of binding precedents upon them no matter how absurd or illogical the consequences might be. See London St. Tramways Ltd. v. London County Council, [1898] A.C. 375, 380-81; Beamish v. Beamish, [1861] 9 H.C.L. 274, 338-39. See also Keighley, Maxsted \& Co. v. Durant, [1901] A.C. 240, 244; Quinn v. Leathem, [1901] A.C. 495, 506 (Ire.). The rule was not abolished until 1966. Practice Statement, [1966] 1 W.L.R. 1234.

${ }^{9}$ The annual length of the statute book doubled between 1945 and 1965 , and since 1965 it has grown from about 1,800 pages to over 2,600 in 1975. There has been a similar explosion in the volume of delegated legislation. In the 20 years from 1951 to 1970 , over 43,000 statutory instruments were made, an average of over 2,000 a year, or nearly double the number at the beginning of the century. 
the legislative scrutiny of executive action. ${ }^{10}$ Parliamentary Questions to Ministers also have increased dramatically in number. ${ }^{11}$ Without going as far as Professor Goodhart, who, in the course of his Roberts Lecture, described Question Time as "the most effective machinery that has ever been devised for the control of the executive by the legislature," 12 I feel that it is undoubtedly one important extrajudicial safeguard. Other safeguards are also, characteristically, extrajudicial. The actions of central government departments recently have been opened to scrutiny by the Parliamentary Commissioner for Administration; those of local government are scrutinised by the Local Commissioners for Administration; and complaints about the National Health Service are now investigated by the Health Service Commissioners. In addition, Parliament has passed some legally enforceable measures to protect specific human rights, such as equality of opportunity regardless of race $^{13}$ or sex. ${ }^{14}$ Impressive standards of administration have been maintained not by legal process but by the integrity and power of a permanent civil service recruited on merit and independent of political influence. Granted that the citizen has far fewer legally enforceable constitutional rights than in most advanced democratic societies, there is wisdom in the recognition in the United Kingdom that the administrative process "is not, and cannot be, a succession of justiciable controversies." 15

At its best, the British constitutional system has worked remarkably well considering the absence of any constitutional framework forming the fundamental and paramount law of the nation. The rationale of the system is contained in the theories

Speech by the Right Honourable Roy Jenkins, M.P., Sec'y of State for the Home Dep't, in Human Rights and Constitutional Change, 1 Human Rights Rev. 191, 193 (1976).

10 "There are now 20 House of Commons Select Committees where even as recently as a decade ago there was only the Select Committee on Nationalised Industries." Id.

11 "The total number of Parliamentary Questions tabled to all Government Departments in the year 1964-65 was about 20,600. Ten years later it had increased to almost 38,000." Id. 194. The great majority of the answers to these Questions were, of course, written rather than oral.

${ }^{12}$ Goodhart, The Rule of Law and Absolute Sovereignty, 106 U. PA. L. REv. 943, 957 (1958).

13 The Race Relations Act 1965, c. 73, in 1 Halsbury's Statutes of England 926 (3d ed. 1968), and The Race Relations Act 1968, c. 71, in 40 Halsbury's Statures of ENGLAND 103 (3d ed. 1972), both of which are now in the process of being repealed and replaced by the Race Relations Bill 1976.

${ }^{14}$ Sex Discrimination Act 1975, c. 65, in 45 Halsbury's Statutes of England 221 (3d ed. 1976).

${ }^{15}$ S.A. de Smith, Judicial Review of Administrative Action 3 (3d ed. 1973). 
of the Utilitarian philosophers-men like Bentham, Austin, and Dicey-who gloried in the unrestricted legislative sovereignty of the Imperial Parliament of Westminster as much as they despised the "nonsense on stilts" of natural and imprescriptible rights. They described the various parts of the constitution with the deceptive certainty and lucidity of theorems of geometry: what Bagehot called the "dignified parts" that "excite and preserve the reverence of the population" and the "efficient parts" by which it "in fact works and rules."16

The best conditions for the working of the system were those of Victorian society: a society, self-conscious in its homogeneity and insularity, that overshadowed its professed ideals of tolerance and fair play; a society rejoicing in its abundant wealth, the fruits of early industrialisation and exploitation of a vast empire; a society of laissez-faire, in which there was minimal legislative intervention by Parliament and in which the protection of property and contract rights was the dominant concern of the courts; a society administered at home and abroad by a new breed of Platonic guardians, permanent, wellpaid civil servants educated in the classics and recruited on merit; a society whose Imperial Parliament was not subjected to the pressures of highly organised political parties, strong trade unions, a mass electorate, and mass communications, as well as the centrifugal forces of nationalism and self-determination.

In such an age it was natural to extol the virtues of an omnicompetent Parliament working in partnership with an independent judiciary to uphold fair play and the supremacy of the rule of law. The British, so it seemed to them, had no need for written constitutions and fundamental rights. Their Parliament would make the rules flexibly as and when necessary. Like children playing with toy soldiers, they found power delightful and absolute power absolutely delightful.

By the end of the century conditions were changing rapidly, and the pace of change accelerated during and after the First World War. But the influence of Benthamite constitutional theory endured and continues to dominate the public philosophy in Britain that I have described. And I believe that its influence has been and will continue to be harmful to those rights and freedoms that should be part of the positive content and value of citizenship itself. 
One vivid example of its baneful influence arose in connection with the Irish Question; and the consequences still haunt us in Northern Ireland, where deaths and injuries are inflicted daily by bomb and bullet on a scale unparalleled elsewhere in the West. After Gladstone's conversion to Home Rule, he tried twice, without success, in 1889 and 1893, to persuade Parliament to create a federal relationship between Britain and Ireland. Asquith tried again but was defeated by the outbreak of the First World War. The most ardent legal opponent of these measures outside Parliament was Dicey, whose enthusiasm for the Unionist cause eventually led him to turn his back even on his two fundamental principles of Parliamentary sovereignty and the rule of law. ${ }^{17}$ In 1913, Dicey contended that if Asquith's Home Rule Bill were enacted by Parliament, it would have no constitutional validity as a law; he also argued that it would be justifiable for the Ulster Unionists to resort to rebellion, if necessary, to prevent Irish Home Rule.

Making every allowance for the danger of exaggerating the influence of constitutional and legal structures, it is at least arguable that the course of Irish history would have been different if the Westminster Parliament had created a federal constitutional structure for Britain and Ireland, complete with a justiciable Bill of Rights. It is also arguable ${ }^{18}$ that the present tragedy in Northern Ireland might have been avoided if Lloyd George's Act of 1920 had not granted virtually exclusive power ${ }^{19}$ to the Northern Ireland Parliament. One is bound to ask whether human rights might not have been better protected during the half century of devolved government in Northern Ireland with the support of a Bill of Rights liberally interpreted and actively enforced by the judiciary.

The absence of a constitutional framework forming the fundamental and paramount law of the nation now threatens to

${ }^{17}$ A.V. Dicey, A Fool's Paradise: Being a Constitutionalist's Criticism on the Home Rule BILl of 1912, at xxix, 117, 121, 127 (1913) [hereinafter cited as A Fool's Paradise]. See also A.V. Dicey, England's Case Against Home Rule (1886); A.V. Dicey, Letrers on Unionist Delusions (1887); A.V. Dicey, A Leap in the Dark or OUR NeW Constitution (1893).

${ }^{18}$ But see K. Boyle, T. Hadden \& P. Hillyard, Law and State: The Case of NoRTHERN IRELAND 10-15 (1975), which argues that, apart from the absence of formal guarantees of basic civil rights in the British and Northern Irish constitutions, the necessary confidence in the judicial system was also lacking in Northern Ireland.

${ }^{19}$ See, e.g., Donaldson, The Constitution of Northern Ireland: Its Origins and Development, 11 U. TORONTO L.J. 1, 41 (1955). 
be as harmful in relation to the Scottish Question ${ }^{20}$ as it has been in relation to the Irish Question. The Scottish Question, which is also to a lesser extent the Welsh Question, is how to meet legitimate demands for greater self-government in those parts of the United Kingdom without destroying the national framework of the United Kingdom as a whole. The preparatory work on proposals for the devolution or transfer of power to Scotland and Wales was undertaken by the [Kilbrandon] Royal Commission on the Constitution. The Kilbrandon Report ${ }^{21}$ recommended the transfer of substantial powers to Scottish and Welsh Assemblies and executive bodies. But it rejected a federal solution including a justiciable Bill of Rights, ${ }^{22}$ on the basis of facile arguments that might have been written by Dicey himself. The report, like so many previous British commentaries, did not comprehend the strongly unifying character of a federal system in maintaining a national framework for a plural society. Unfortunately, however, the British Government accepted the Kilbrandon Report's view. ${ }^{23}$ It is characteristic of the influence of Parliamentary sovereignty and the distrust of justiciable constitutional rights that the Government originally found it necessary to leave open ${ }^{24}$ the question whether there should be any judicial review at all of the exercise of the legislative powers of the proposed Scottish Assembly. The Government eventually decided in favour of judicial review, ${ }^{25}$ but there is no indication that it contemplates that the courts will apply general constitutional criteria in determining whether the legislative or executive actions of the Scottish administration are compatible with the economic and political unity of the United Kingdom and the rights and liberties of its citizens. In the absence of a written

${ }^{20}$ In view of the recent growth of Scottish nationalism, it is interesting to recall that a scheme to reconstitute the United Kingdom as a federal state including England, Scotland, Wales, and Ireland was opposed so strongly by Dicey that he collaborated in writing a book to discredit the proposals. A.V. DicEY \& R. RAIT, Thoughts on THE UNion BetweEn ENGLaNd and Scotrand (1920). For a further indication of Dicey's reaction, see the entry by Rait under "Dicey" in the Dictronary of National BIOGRAPHY, 1922-1930 (1937).

21 RePort of the Royal Commission on the Constitution, 1969-1973, CMnd. No. 5460 (1973).

${ }^{22}$ Id. ๆी 538-39, 746-55.

23 Democracy and Devolution-Proposals for Scotland and Wales, Cmnd. No. 5732 , at If 2 (1974).

24 Our Changing Democracy: Devolution to Scotland and Wales, Cmind. No. 6348 , at $1962-65$ (1975).

${ }^{25}$ Devolution to Scotland and Wales: Supplementary Statement, Cmnd. No. 6585 , at 114 (1976). 
constitution, such criteria would have to be devised specially to be included in the forthcoming Devolution Bill.

I shall give an example of the potential problem that will be readily familiar to any American constitutional lawyer. Let us make the considerable assumption that the Devolution Bill, unlike the abortive Irish Home Rule Bills, will be approved by Parliament during the coming session. Let us make the further, not improbable, assumption that the Scottish Assembly then established will be dominated by members of the Scottish National Party seeking to secede from the Union and therefore eager to provoke conflicts about matters of policy between the Assembly in Edinburgh and the central government in London. Suppose that the Scottish Assembly passes an enabling measure in the field of road service licensing, a field expressly devolved to them by the Westminster Parliament. On its face the Scottish measure is apparently within the powers devolved to the Scottish Assembly. It provides for the appointment of a regulatory agency with the function of licensing road transport in Scotland. The Scottish Road Transport Commission is duly appointed, but it proceeds to impose conditions that discriminate against vehicle owners or users who have not been born in, or are not residents of, Scotland.

What would happen under your system? Presumably, the Supreme Court would decide that the discriminatory measure is unconstitutional whether because it is incompatible with the power of Congress to regulate interstate commerce or because it constitutes a denial of the equal protection of the laws.

What would happen under our system? We have no written constitution, no commerce clause, and no fourteenth amendment. The scope of judicial review therefore would be confined to deciding whether the substance of the Scottish legislation is within the powers conferred by the Westminster Parliament in the Devolution Act. And barring some radical departure from the traditional approach of the judiciary, ${ }^{26}$ review would be limited to a textual analysis of the language of the Devolution Act, the Scottish Road Transport Act, and the Scottish Road Transport (Licensing) Regulations to determine the "pith and substance" of the Scottish measures. Unlike the United States

${ }^{26}$ See, e.g., Shannon v. Lower Mainland Dairy Prods. Bd., [1938] A.C. 708 (P.C.); Gallagher v. Lynn, [1937] A.C. 863 (Northern Ire.). 
Supreme Court, ${ }^{27}$ our courts would not consider the practical consequences of the operation of the Regulations for freedom of commerce and equality of citizenship. Our courts would have no general constitutional criteria against which to test the validity of the Scottish Regulations, and, provided that the subject of road transport licensing was within an expressly devolved field, the courts would be likely to declare that the Regulations and their application were lawful.

What would happen then? A blatantly discriminatory measure would have received judicial blessing. If the central government were able and willing to intervene by relying upon the sovereignty ${ }^{28}$ of the Westminster Parliament to exercise overriding powers, it would thereby risk arousing resentment sand strengthening the forces of separatism in Scotland. If the central government were unable or unwilling to intervene, the fundamental economic unity and freedom of commerce of the United Kingdom would be impaired and citizens of the United Kingdom would be denied equal protection of the laws.

We British shall ignore at our peril Dean Griswold's reminder that the United States Supreme Court's use of the commerce clause enabled you to become and to remain a nation. ${ }^{29}$

${ }^{27}$ See, e.g., Dean Milk Co. v. City of Madison, 340 U.S. 349 (1951); Cooley v. Board of Wardens, 53 U.S. (12 How.) 299 (1851).

${ }^{28}$ For sound historical and legal reasons, Dicey's view that the Westminster Parliament has absolute sovereign powers to abrogate any provision of the Act of Union (including Article XVIII) has not to this day been accepted by the Scottish judiciary. See, e.g., MacCormick v. Lord Advocate, [1953] Sess. Cas. 396; Gibson v. Lord Advocate, [1975] Scot. L.T.R. 134.

${ }^{29}$ E. Griswold, Law and Lawyers in the United States 88 (1964). Dean Griswold went on to observe:

In this respect, our Founding Fathers proved to be more far-seeing . . .

than did the draftsmen of the British North American Act . . . who, while making use of some parts of the American Constitution, did not adopt the Commerce Clause. The allocation in Canada of power over specific areas, such as banking, to the Federal Government has not been as effective in actual operation as is the general power given to Congress by the Commerce Clause.

Id. 88-89. I wonder, however, whether Dean Griswold is right in blaming the British draftsmen rather than the judiciary. The only guidance contained in the words of the commerce clause is that "Congress shall have Power ... To regulate Commerce with foreign Nations, and among the several States, and with the Indian Tribes." It was Chief Justice Marshall's creative interpretation of these words in Gibbons v. Ogden, 22 U.S. (9 Wheat.) 1 (1824), that enabled the commerce clause to have its subsequent crucial unifying character. Section 91 of the British North America Act 1867 enumerated "the regulation of trade and commerce" as a class of subject over which the Dominion has exclusive legislative powers. It was open to the Judicial Committee of the Privy Council to interpret this provision as a commerce clause. Instead, it has fairly been observed that "judicial misconstruction ... [of the British North America Act] has 
Without the commerce clause, as he says, you would have had what has been called the Balkanisation of the United States. And I would add that we British shall also ignore at our peril the Supreme Court's use of the fourteenth amendment, which enabled you to become and to remain a nation dedicated to equal justice under the law.

In the immediate future we shall probably ignore truths that must seem to you to be self-evident. But eventually-and I would hope sooner rather than later-the threat of the Balkanisation of the United Kingdom may result in a new constitutional settlement that draws from your experience.

The Scottish and Northern Irish Questions are not the only considerations for those, like myself, who seek a constitutional resettlement. There is widespread discontent with our constitutional system, the causes of which are complex. Parliament and the civil service machine are creaking under the ever-increasing volume of legislation, some of which is highly controversial in matters that you would regard as affecting fundamental rights. The electoral system is less than fair in its effect. Occasionally, the central government, of whatever political colour, seems like a Juggernaut, ignoring what may be a minority position both in Parliament and amongst the electorate, and whipping its Parliamentary followers to force through fundamental constitutional changes. ${ }^{30}$ The absence of constitutional standards, given new life and meaning from generation to generation by a supreme constitutional court, means that laws are made that may affect fundamenta!s, suck as those defined and protected in your

nullified, with only a few exceptions, the residuary power of the Dominion, and has transferred this power to provincial domain under the guise of property and civil rights." D. Schmeiser, Civil Liberties in Canada 9 (1964). With regard to the particular example of the regulation of trade and commerce, see, e.g., Attorney-General for British Columbia v. Attorney-General for Canada, [1937] A.C. 377 (P.C.); Citizens Ins. Co. of Canada v. Parsons, 7 App. Cas. 96 (1881). A similar criticism may be made of the House of Lords' interpretation of $\S 4$ of the Government of Ireland Act 1920, which provided that "the Parliament of Northern Ireland shall . . . not have power to make laws in respect of . . . [t]rade with any place out of the part of Ireland within their jurisdiction [with certain limited and immaterial exceptions]." See Gallagher v. Lynn, [1937] A.C. 863, 864-65.

${ }^{30}$ Even Dicey, the exponent of the proposition that neither the Act of Union with Scotland nor the Dentists Act had more claim to be considered a supreme law, was driven by his support for the Ulster Unionist cause to conclude that the risk that a party majority might grossly misrepresent the will of the nation, "combined with the gradual development of democracy, adds immense force to the argument that in England it is as necessary, as it is in the United States, that every great constitutional change should receive the direct sanction of the electors." A FOOL's PARADISE, supra note 17, at $121 \mathrm{n} .1$. 
Bill of Rights, yet their fundamental implications tend to become apparent in Britain only if vigilant and well-informed individual Parliamentarians or journalists make them so. We have no body comparable to the great French Conseil d'Etat that scrutinises legislation before it is introduced in Parliament to ensure that it conforms with general principles of law; ${ }^{31}$ or that prevents unwarranted encroachments by central, devolved, regional, or local governments into each other's respective spheres; ${ }^{32}$ or that provides fully comprehensive and effective legal remedies against administrative abuse. ${ }^{33}$ These are some of the unsatisfactory

${ }^{31}$ See L.N. Brown \& J. Garner, French Administrative Law 118-26 (2d ed. 1973); M. Rendel, The Administrative Functions of the French Conseil d'Etat (1970). In England and Wales, Parliamentary Counsel draft bills for the Government's legislative programme and also advise Ministers and civil servants on questions concerning Parliamentary practice and procedure, constitutional matters, and on occasion, the interpretation of statutes. They number at present only 23. (RENTON) REPORT ON THE Preparation of Legislation, CMnd. No. 6053, at If 3.1, .2 (1975). It would be impossible for the Office of Parliamentary Counsel to perform functions similar to those of the Administrative Sections of the Counseil d'Etat in independently scrutinising all legislation before it is introduced in the Assemblée Nationale. Parliamentary Counsel are not independent of the initial drafting process. On the contrary, they have exclusive responsibility for drafting primary legislation on the Government's behalf. Moreover, there are no principles analogous to the French general principles of law against which Parliamentary Counsel or any other body could at present evaluate proposed legislation. In the case of subordinate legislation, Parliamentary Counsel perform almost no role because all subordinate legislation is now drafted in the legal branches of Government departments. Id. I 3.2. In the context of devolution to Scotland, the Government has now decided that if there is doubt about a Scottish Assembly bill, the final decision will lie with the Judicial Committee of the Privy Council. Devolution to Scotland and Wales: Supplementary Statement, CMnd. No. 6585, at 12 (1976). Given, however, that the composition of the Privy Council is exclusively judicial and given the absence of any general guiding principles in the forthcoming Devolution Bill, such a process will again not approximate the impressive work of the Administrative Sections of the Conseil d'Etat. Moreover, it is not clear what effect the Privy Council's approval of an Assembly bill will have on the judicial review of the measure after it has entered into force.

${ }^{32}$ The traditional English judicial approach to this subject is exemplified by the following passage from the leading case of Kruse v. Johnson, [1898] 2 Q.B. 91, 98-100, per Lord Russell of Killowen, C.J.:

Parliament has thought fit to delegate to representative public bodies in towns and cities, and also in counties, the power of exercising their own judgment as to what are the by-laws which to them seem proper to be made for good rule and government in their own localities. ... The power is to make by-laws from time to time as to the authority shall seem met, and if experience shews that in any respect existing by-laws work hardly or inconveniently, the local authority, acted upon by the public opinion, as it must necessarily be, of those concerned, has full power to repeal or alter them. ... . [S]hould experience warrant that course, the Legislature which has given may modify or take away the powers they have delegated. . . . [W] $W$ hen the Court is called upon to consider the by-laws clothed with the ample authority . . . accompanied by the checks and safeguards which have been mentioned ... [t]hey ought to be . . ."benevolently" interpreted, and credit ought to be given to those who have to administer them that they will be reasonably administered.

${ }^{33}$ The Law Commission has recommended repeatedly that an inquiry into the ex- 
features of our system that are strengthening the movement -courageously led from the Bench by Lord Justice Scar$\operatorname{man}^{34}$ - for a constitutional resettlement, including a written constitution and fundamental constitutional rights, judicially enforced. In the longer term, another crucial influence, to which I shall refer later, will be the effect of the United Kingdom's membership of the new European institutions.

But I shall now digress and explain the dilemma of the British law reformer, in this field as elsewhere. We depend upon the judges to carry out and even to initiate desirable reforms; but given both the public philosophy of judicial restraint and the past judicial record, strong and reasonable doubts arise concerning the readiness and ability of the British judiciary to do so. The problem cannot be explained solely in terms of "the helplessness of the law in [the] face of the legislative sovereignty of Parliament,"35 although this does have a pervasive influence. Again and again our courts have been narrowly restrictive even when the constraints of Parliamentary sovereignty did not preclude a more liberal judicial approach. Could they be trusted to change their habits of mind if they were given wider constitutional powers? That is the dilemma.

\section{COURTS As INTERPRETERS OF Race Relations Legislation}

I shall illustrate the problem from the field of race relations. Issues involving race discrimination have come before English judges in three capacities: first, as members of the Judicial Committee of the Privy Council, which is the supreme court of appeal for British colonies and some independent Commonwealth countries; secondly, as interpreters of the common law; and thirdly, as interpreters of race relations legislation. I have

isting state of administrative law should be carried out by a Royal Commission or committee of comparable status. See Law Commission No. 20, CMnd. No. 4059 (1969); Law Commission No. 73, CMnd. No. 6407 (1976). Despite recent changes in judicial attitudes towards the review of administrative action, the major procedural and substantive defects in English administrative law could be rectified only by legislation. As yet, however, the Law Commission's recommendation has remained unheeded. It is not surprising that British administrators should be unattracted by the recommendation, both for the obvious reason that it might result in greater legal intervention in their actions, and for the less obvious reason that, unlike their continental European counterparts, they have never shared in the adjudicative process.

${ }^{34}$ See, e.g., L. Scarman, English Law-The New Dimension (1974).

${ }^{35} \mathrm{Id} .15$. 
discussed elsewhere their record in deciding appeals to the Privy Council and in interpreting the common law. ${ }^{36}$

I shall therefore concentrate upon the third capacity in which the courts have faced the problem, namely, as interpreters of Parliamentary legislation. The Race Relations Act 1968 prohibits discrimination on the ground of colour, race, or ethnic or national origins in a wide range of situations, including employment, housing, education, and the provision of goods, facilities, or services to the public. Four cases have been decided by the House of Lords under the present Act, all of which raised difficult questions of statutory interpretation.

In the first case, ${ }^{37}$ a local government authority adopted a rule that a condition of acceptance on its waiting list for public housing was that "an applicant must be a British subject." It therefore refused to place a Polish national on the list. The question was whether it thereby had discriminated on the basis of "national origins." The High Court judge decided that it had acted unlawfully. Inasmuch as a person's national origins dictate his original nationality and the vast majority of people retain their nationality of origin, the practical effect of the condition was to place the vast majority of people of other national origins in a less favourable position than almost all people of British or Commonwealth origin, and thus to discriminate on the ground of national origins. It was a common-sense approach that looked to the practical effect of the condition. The House of Lords, however, adopted a more technical approach. In their view, the phrase "national origins" meant something akin to race. The ground of the discrimination was that the applicant was not a British subject. "It was his nationality at the time when he applied, not his national origins, that led to the refusal to put his name on the waiting list." 38

Each of the next two cases concerned alleged colour discrimination by social clubs, and the issue was whether the clubs were persons concerned with the provisions of facilities and services to "a section of the public." In both cases, the Court of Appeal decided that they were within the statute, and the Lords decided otherwise.

\footnotetext{
${ }^{36}$ A. Lester \& G. Bindman, Race and Law in Great Britain 23-72 (1972).

${ }^{37}$ Ealing London Borough Council v. Race Relations Bd., [1972] A.C. 342; cf. Espinoza v. Farah Mfg. Co., 414 U.S. 86 (1973).

${ }^{38}$ Ealing London Borough Council v. Race Relations Bd., [1972] A.C. 342, 359 (Viscount Dilhorne).
} 
In one of these two cases, ${ }^{39}$ a Conservative Club rejected the application for membership of an Indian allegedly on the ground of his colour. Any man of eighteen was eligible for membership in the Club if he was a Conservative and duly proposed and seconded. The Court of Appeal held ${ }^{40}$ that the quality distinguishing potential members of the Club from others-that is, men of eighteen who were Conservatives duly proposed and seconded-was essentia!ly impersonal so that potential members were a section of the public within the meaning of the Act. But the House of Lords treated the words "section of the public" as words of limitation and held that a club, a private association of individuals, was outside the Act if its election rules provided a genuine process of selection that was followed in practice.

In the other case, ${ }^{41}$ a Dockers' Club that operated a colour bar was linked with four thousand other working men's clubs in an association affording admission to any member of any associated club. A coloured member of one of the associated clubs was asked to leave the Dockers' Club. The Court of Appeal distinguished the Lords' decision in the Conservative Club case on the ground that in the case of the Lockers' Club, although members elected by a bona fide process constituted a private group, approximately a million members of other clubs had associate members' rights in the Dockers' Club without having been personally approved by it and were therefore a section of the public. The Lords decided otherwise, however. In their view, the policy of the Act was to separate the public from the private sphere, and numbers as such were therefore irrelevant. Lord Diplock suggested that the relevant test was: "Would a notice 'Public Not Admitted', exhibited on the premises on which the goods, facilities or services were provided, be true?" 42

At first sight one might think that the Lords' decision was more rational and certain in its effects than the common-sense fact-and-degree approach of the Court of Appeal. But I respectfully doubt whether this is so. ${ }^{43}$ The proposition "a club is a club is a club" is acceptable as a line of Dadaist poetry, tending to

${ }^{39}$ Charter v. Race Relations Bd., [1973] A.C. 868.

40 Race Relations Bd. v. Charter, [1972] 1 Q.B. 545 (C.A.).

${ }^{41}$ Dockers' Labour CIub \& Inst., Ltd. v. Race Relations Bd., [1976] A.C. 285, rev'g [1974] Q.B. 503 (C.A.).

42 [1976] A.C. 285, 297.

${ }^{43}$ Contra, R. Cross, Statutory Interpretation 72-74 (1976). 
suppress any connection between thought and expression; but it affords no rational basis for excluding from the ambit of the Race Relations Act all social clubs per se, including some four thousand clubs linked together in a profitable commercial association and providing their services to any of a million associated members. Nor does the addition of the label "private" to such clubs increase the rationality of these decisions. Of course clubs are private in character and could truthfully exhibit a notice on their premises saying "Public Not Admitted," but so could a landlord, the management of the Ritz Hotel, or the Fellows of Trinity College, Cambridge, all of whom are plainly within the scope of the statute. The test of fact and degree is surely preferable to a labeling distinction that is mere verbalism.

In the fourth case, the Lords agreed ${ }^{44}$ with the Court of Appeal that foster parents registered with a local authority provided facilities and services to a section of the public by looking after children in the care of the local authority. The situation was not one of a purely domestic character because foster parents made a practice of taking in any child for whom a home was required. Although the foster parents undertook to treat and did treat the children as members of their own family, the children in fact were not members of the family. Accordingly, foster parents could not lawfully refuse on racial grounds to accept a child who had been referred to them.

The odd aspect of this case is that it relates to precisely the type of situation in which one would have thought that a distinction between the public and private spheres should be made. What could be more private than the relationship between foster parents and children whom they have undertaken to treat as members of their family? What could be more relevant to the welfare of a black child than the fact that a potential foster parent was racially prejudiced? What could be more questionable than a conclusion that depended upon saying that foster children were not really members of the family, unlike, for example, adopted children? ${ }^{45}$

The new Race Relations Bill that is now before Parliament seeks to reverse the effect of all four decisions by the Lords. ${ }^{46}$ And I think that these decisions illustrate why there is some

${ }^{44}$ Applin v. Race Relations Bd., [1975] A.C. 259.

${ }^{45}$ Lord Wilberforce made this point in a powerful dissenting speech. Id. at 279-82.

${ }^{46}$ See Racial Discrimination, CMnd. No. 6234, at 9 I 56, 72-73 (1975); Race Relations Bill, clauses I(1), 3(1), 23(2), 25 (as brought from the Commons, July 9, 1976). 
disquiet about the effect of giving a wider lawmaking role to the judiciary. The grounds for disquiet will not be removed merely by changing drafting techniques to include broad general principles in Acts of Parliament, even though such changes would be beneficial. ${ }^{47}$ What matters is the judicial approach to the interpretation of all statutory language, whether general or specific. And what is needed is a more European ${ }^{48}$ or American approach.

In preparing the recent legislation against sex and race discrimination, the British Government was influenced by the way in which the concept of discrimination had been developed by the United States Supreme Court in interpreting the Civil Rights Act of $1964 .{ }^{49}$ In Griggs v. Duke Power Co.,${ }^{50}$ the Supreme Court had to decide whether Title VII prohibited the use of tests or criteria for employment or promotion that were not racially motivated but that were discriminatory in effect against blacks and unrelated to job performance. Chief Justice Burger, deliver-

47 The (Renton) Report on the Preparation of Legislation, supra note 31, recommended that "encouragement should be given to the use of statements of principle, that is to say, the formulation of broad general rules" in Parliamentary drafting. Id. I 10.13. The report, however, considered that legislating by statement of general principle might "be more acceptable for private law governing the dealings of individuals and non-State corporations one with another than for public law ... governing relations between the State and its individual or corporate subjects." Id. I 10.12. It is to be hoped that the Renton Committee had in mind laws imposing duties and liabilities upon individual or corporate subjects of the state and not laws conferring fundamental rights and freedoms. The real problem about the interpretation of Acts drafted in a simpler, less detailed, and less elaborate style than at present is, as the Renton Report concluded, a problem of confidence: "Would Parliament be prepared to trust the courts?" Id. II 19.41 .

${ }^{48}$ See, e.g., D. Lasok \& J. Bridge, An Introduction to the Law and INstrututions of the European CoMmunitres 43-47, 91-100 (2d ed. 1976). Lord Denning has given the following guidance for English courts in interpreting the Rome Treaty or a Community instrument:

They must follow the European pattern. No longer must they examine the words in meticulous detail. No longer must they argue about the precise grammatical sense. They must look to the purpose or intent. To quote the words of the European Court ... they must deduce "from the wording and the spirit of the Treaty the meaning of the community rules". . . They must divine the spirit of the Treaty and gain inspiration from it. If they find a gap, they must fill it as best they can. They must do what the framers of the instrument would have done if they had thought about it. So we must do the same. Those are the principles, as I understand it, on which the European Court acts.

H.P. Bulmer Ltd. v. J. Bollinger S.A., [1974] Ch. 401, 426 (C.A.). The American reader no doubt will wonder why these are not appropriate principles for the interpretation of United Kingdom legislation.

49 The original source of this influence was L. Pollak, Discrimination in Employment: The American Response (1974).

50401 U.S. 424 (1971). But see Washington v. Davis, 96 S. Ct. 2040 (1976). 
ing the opinion of the Court, recalled Aesop's fable about the fox's cruel trick in offering milk to the stork in a flat bowl and the stork's revenge in serving food to the fox in a narrow-necked pitcher. Chief Justice Burger said that Congress had provided that tests or criteria for employment or promotion

may not provide equality of opportunity merely in the sense of the fabled offer of milk to the stork and the fox. On the contrary, Congress has now required that the posture and condition of the job-seeker be taken into account. It has ... provided that the vessel in which the milk is proffered be one all seekers can use. The Act proscribes not only overt discrimination but also practices that are fair in form, but discriminatory in operation. The touchstone is business necessity. ${ }^{51}$

In drafting our new antidiscrimination legislation, we have learned from the Supreme Court's wisdom. The legislation makes unlawful not only overt and deliberate discrimination, but also conditions or requirements that in effect discriminate or are likely to discriminate against one sex or racial group and that are not shown to be justifiable. ${ }^{52}$ It is highly improbable that our courts would have reached this result by interpreting the existing Race Relations Act; it therefore had to be done by Parliament. It remains to be seen how our courts and industrial tribunals will exercise the substantial lawmaking functions conferred upon them by these broad provisions.

Substantial difficulties and limitations, however, are presented by the Griggs approach. It involves some adjustment of the classical theory of equal opportunity, which is based upon individual merit and is sex- and colour-blind. Group reasoning becomes central to the argument; and group reasoning may be easily misinterpreted to mean that there are objective differences between the sexes or races that justify quotas or other forms of alleged favouritism. Nor is the argument likely to be buttressed by the search for past guilt-the notion that because your father may have discriminated against my mother on grounds of sex, my daughter is entitled to be treated more favourably than your son. I have no doubt about the moral and practical validity of the

51401 U.S. at 431 .

${ }^{52}$ See Sex Discrimination Act 1975, c. 65, $\$ \S 1(1)(b), 3(1)(b), 37$, in 45 HalsBury's Statutes of ENGland 221 (3d ed. 1976); Race Relations Bill, clauses 1(2)(b), 28 (as brought from the Commons, July 9,1976 ). 
policy that acknowledges the effects of past discrimination and the real inequalities that afflict particular groups; but it is more difficult to apply Aesop's fable to men and women and to blacks and whites, than to foxes and storks, however morally justifiable the policy may be and however strongly one may assert a common humanity.

Moreover, what no judge can do, even in this nation of juidicial activism, is to ensure that special provision is made for special needs, whether of women or of racial minorities. A judge can tackle overt discrimination and some of the continuing effects of past discrimination; but he cannot ensure that adequate provision is made, for example, to alleviate the unequal demands made upon women-the demands that have been made of them to be wage-earners as well as mothers and housekeepers. Only a family policy, devised and executed by government, could remove this most enduring source of the inequality of women. ${ }^{53}$

\section{The European Dimension}

I now return to my principal theme: the forces that may lead to a new constitutional settlement in the United Kingdom, with legal guarantees of fundamental rights. The most important influence of all, more important than the pressures of Scottish devolution or existing discontents with the present constitutional system, will, I believe, be the European dimension.

The United Kingdom is bound in international law to comply with the obligations contained in two European instruments to which it is a contracting party: the European Convention on Human Rights, which has been ratified by all member states of the Council of Europe, and the Treaty of Rome, which established the European Economic Community.

\section{A. The European Human Rights Convention}

The first of these two instruments-the European Human Rights Convention and its amending Protocols ${ }^{54}$ - contains an international Bill of Rights guaranteeing, for example, the right to life; freedom from inhuman and degrading treatment or punishment; freedom from slavery or servitude; the right to

${ }^{53}$ See, e.g., Blackstone, The Limits of Legislating for Equality for Women, 5 NEw Communiry 22 (1976); Nandy \& Nandy, Towards True Equality for Women, id. 31.

${ }^{54}$ See Council of Europe, European Convention on Human Rights: Collected Texts (10th ed. 1975). The United Kingdom Government has not ratified the Fourth Protocol to the Convention. 
protection against arbitrary arrest or detention; the right to fair civil and criminal procedures; freedom from ex post facto criminal laws; the right to respect for family life, home, and correspondence; freedom of thought, conscience, religion, expression, and association; the right to marry and to found a family; the right to the peaceful enjoyment of one's possessions; the right to education; and the right to enjoy these rights and freedoms without discrimination.

The Convention enables interstate cases to be brought for alleged breaches of its provisions. But what is of greater practical significance is that if, as is the case with the United Kingdom and most other states parties, the right of individual petition has been accepted, individuals may complain to the European Commission of Human Rights in Strasbourg of alleged violations of their Convention rights and freedoms by a particular state. And if the Commission upholds a complaint, the case may be referred to the European Court of Human Rights for final judgment. ${ }^{55}$

The Convention is part of the internal law of many of the contracting states, either because as an international treaty it automatically has that effect or because it has been incorporated into their internal law by specific legislation. We have not incorporated the Convention into United Kingdom law, however. And because, unlike most other Western European countries, we lack legally-enforceable constitutional guarantees and a comprehensive system of administrative law, fewer possibilities of effective domestic remedies have to be exhausted by an alleged victim in the United Kingdom before recourse may be had to the Strasbourg machinery.

I shall give two brief examples to illustrate the impact of the Convention. In 1967, as a result of a policy of "Africanisation," United Kingdom passport holders of Asian origin began to be expelled from Kenya and Uganda. At that time they were legally entitled to come to Britain, and they did so in increasing numbers. Many of them had relied on their right to enter the United Kingdom in deciding not to opt for local citizenship in Kenya and Uganda during the period when the option had been available to them. As the result of a racially inspired campaign, the British Government reacted in February 1968 by depriving these

55 The only interstate case to have been referred to the European Court is the Irish State Case between the Republic of Ireland and the United Kingdom. The Commission's report was adopted on January 25, 1976, and the case is at present pending before the Court. 
British Asians, approximately 200,000 in number, of their right of entry and by substituting instead a quota system that was estimated to phase their future entry into the United Kingdom over a period of thirty years. ${ }^{56}$ The legislation, although highly controversial, was driven through all its stages in both Houses of Parliament in only three days. Thereafter, many British Asians were trapped in East Africa and became destitute refugees. Others who attempted to enter Britain were shuttle-cocked in aircraft to and fro across the world. Some of them complained to the European Human Rights Commission that the legislation was racially motivated and that its application to them had violated their Convention rights. They claimed, in particular, that the British Government, by discriminating between different groups of citizens on racial grounds, had subjected the British Asians to treatment that was inherently degrading. ${ }^{57}$ In due course, the Commission reached its decision. Its report has not been published, but it is widely understood that the Commission concluded that the Convention had been violated. The British Government did not refer the case to the European Court, and it is therefore now being considered by the Committee of Ministers of the Council of Europe. Meanwhile, the rate of entry of the British Asians has been greatly accelerated so that all of them probably will be settled in Britain in the near future. Here then is a dramatic example of an Act of Parliament successfully challenged before an international Commission on the basis of an international Bill of Rights.

The second case is more mundane. Mr. Golder was a prisoner who had been refused permission by the Home Secretary to consult a solicitor for the purpose of bringing libel proceedings against a prison officer. The European Commission upheld his complaint, which was then referred to the European Court. The Court decided that the United Kingdom Government had violated the Convention guarantee of the right to a public hearing in the determination of a person's civil rights. ${ }^{58}$ It interpreted this guarantee to include a right of access to the courts. As a result of its judgment, changes were made to the Prison Rules. This was an example of subordinate legislation and the

${ }^{56}$ See Commonwealth Immigrants Act 1968, c. 9, § 1, in 4 Halsbury's Statutes of ENGland 60 (3d ed. 1968); D. Steel, No Entry: The Background and Implications of The Commonwealth Immigrants Act, 1968, at 146-56 (i969).

${ }^{57}$ Compare Trop v. Dulles, 356 U.S. 86 (1958) (plurality opinion by Chief Justice Warren), with Strauder v. West Virginia, 100 U.S. 303 (1880).

${ }^{58}$ Judgment of Feb. 21, 1975, E.C.H.R. Series A Vol. 18. 
exercise of administrative discretion successfully challenged on the international plane when the individual would have had no such right under English law.

Interestingly enough, although the Convention has not been incorporated into United Kingdom law, the House of Lords and the Court of Appeal are already using it as a source of statutory interpretation, with some confused and uncertain results. ${ }^{59}$ The

59 In Regina v. Miah, [1974] 1 W.L.R. 683, 694 (H.L.), Lord Reid, whose speech was approved unanimously by the other members of the House of Lords, stated that in light of Article 7 of the European Convention it was hardly credible that any Government department would promote, or that Parliament would pass, retrospective criminal legislation, and he construed the Immigration Act 1971 accordingly. In Broome v. Cassell \& Co., [1972] A.C. 1027, 1133, Lord Kilbrandon stated that a constitutional right of free speech must be recognised in United Kingdom law at least since the date when the Convention was ratified. In Blathwayt v. Baron Cawley, [1976] A.C. 397, 426 (1975), Lord Wilberforce recognised that a widely accepted treaty, like the Convention, might point the direction in which conceptions of public policy, as applied by the courts, ought to move. In Birdi v. Secretary of State for the Home Dep't, Feb. 11, 1975 (C.A.) (unreported decision), Lord Denning, M.R., stated that the court can and should take the Convention into account when it interprets a statute, such as the Immigration Act, which affects the rights and liberties of the individual, and that the courts should construe statutes to conform with the Convention. He also observed that if a statute does not conform he might be inclined to hold it invalid. In Regina v. Secretary of State for the Home Dep't ex parte Bhajan Singh, [1976] 1 Q.B. 198, 207 (C.A. 1975), Lord Denning reiterated the views he expressed in Birdi with respect to the Convention, and then added:

It is to be assumed that the Crown, in taking its part in legislation, would do nothing which was in conflict with treaties. So the court should now construe the Immigration Act 1971 so as to be in conformity with [the] Convention .... ... [I]mmigration officers and the Secretary of State in exercising their duties ought to bear in mind the principles stated in the Convention. They ought . . . to have regard to [them] because ... they are principles of fair dealing ....

Id. Lord Denning, however, acknowledged that he had not been correct in suggesting in Birdi that if a statute were not in conformity with the Convention the courts might hold the statute invalid. Id.

In Regina v. Secretary of State for the Home Dep't ex parte Phansopkar, [1976] Q.B. 606, 626 (C.A. 1975), Scarman, L.J., stated that it was the duty of public authorities in administering the law-including the Immigration Act 1971-and of the courts in interpreting and applying the law to have regard to the Convention. In Regina v. Chief Immigration Officer, Heathrow Airport, The Times (London), May 12, 1976, at 19, col. 5 (C.A. May 11, 1976), Lord Denning, in referring to his observation in Bhajan Singh that immigration officers ought to bear in mind the principles stated in the Convention, stated that he now thought that this would put too much of a burden on them. They had rules to follow-the rules laid down by the Secretary of State-and if they abided by the rules they could not be called upon to interpret the Convention, particularly as it was expressed in wide generalities in the continental manner. Roskill, L.J., stated that he thought that the statements of Scarman, L.J., in Phansopkar, were somewhat too broad and might call for reconsideration. He also agreed with Lord Denning that he had gone too far in Bhajan Singh and that there were no grounds for imposing on immigration officers the additional burden of considering in every case the application of the Convention.

These decisions have rendered the status of the Convention in United Kingdom law uncertain and unpredictable, and the situation is unlikely to be clarified satisfactor- 


\section{Government has recently published a discussion paper $^{60}$ on the implications of incorporating the Convention into United King-}

ily except by legislation. In view of the conflicting dicta of members of the Court of Appeal, it is unclear whether Ministers or their officials have any duty to have regard to the rights and freedoms defined in the Convention, even though an infringement of those rights and freedoms would constitute a breach of international law by the United Kingdom. One of the reasons given by Lord Denning for not imposing such a duty on immigration officers is that the Convention is expressed in broad generalities in the continental manner. The same, however, may be said, for example, of Article 48 of the Treaty of Rome (freedom of movement for workers without discrimination based on nationality) and Article 3(1) of E.E.C. Council Directive No. 64/221 of February 25, 1964 on the coordination of special measures concerning the movement and residence of foreign nationals (measures taken on grounds of public policy shall be based exclusively on the personal conduct of the individual concerned). The European Court of Justice has held that these provisions are directly applicable and confer on individuals rights that are enforceable by them in the courts of a member state and that must be protected by the national courts. Van Duyn v. Home Office, [1975] 3 All E.R. I90, [1975] I Comm. Mkt. L.R. 1. It would appear to follow, somewhat anomalously, that immigration officers have a duty under European Community law to have regard to these provisions in performing their duties and in exercising their functions in relation to E.E.C. nationals under the Immigration Act 1971, even though they have no duty to have regard to the provisions of the European Convention on Human Rights. It is not clear whether Ministers (as distinct from their officials) would be regarded by the courts as having any duty to have regard to the Convention in exercising their discretionary powers, nor whether subordinate (as distinct from primary) legislation would be regarded by the courts as subject to a presumption of conformity with the Convention. It is also uncertain whether the courts would regard the Convention as a legitimate source from which to derive concepts of public policy in interpreting and applying the common law and, if so, whether they would do so only in cases concerning public authorities or in cases exclusively between private persons.

Sir Leslie Scarman's extrajudicial observations about the use of the Convention by the English judiciary reveals some of the difficulties of the present position:

The legislature must give the judges the criteria or the norms they need in order to reach decisions according to law and not according to some political view or feeling. Philosophically that is the reason for a Bill of Rights. It gives the judges the background they need of criteria and rules. . . [I]n a very unsatisfactory way our judges, and particularly at the moment the Court of Appeal, are seeking after just such criteria by making use of the European Convention to construe British Statutes to which they think the Convention is relevant. It is an extremely unsatisfactory legal position; . . international instruments . . a are not part of our municipal law unless Parliament makes them so. Very occasionally they are incorporated into the law by judicial decision, but that is a very difficult and very narrow entrance indeed.

Nevertheless, because our Courts feel that they need some standards by which, for instance, to construe the immigration legislation, they are turning to the European Convention to provide them with guidance. But what is going to happen? Some judges will gladly turn to the Convention. Others will refuse to do so. You won't be able to criticise either. A very difficult situation is going to arise. When judges are faced with legislation which deals with fundamental human rights and freedoms, such as immigration legislation, you will find them searching for various norms, even though the legislation has not provided them with these: the European Convention is just at the moment to hand.

Centre for Studies in Social Policy, English Law and Social Policy $7-8$ (1976)

(symposium based on Sir Leslie Scarman's 1974 Hamlyn Lectures).

${ }^{60}$ Legislation on Human Rights (1976). 
dom law. If and when incorporation occurs, the British judiciary will be called upon to interpret a legally enforceable Bill of Rights in the light of the jurisprudence of the Strasbourg Court.

\section{B. The Treaty of Rome}

I now turn to the second of the European instruments, the Treaty of Rome. The impact of the United Kingdom's membership in the European Community is increasingly significant. When we joined the Community, the implications of membership for the rights and freedoms of the individual were apparently not fully understood. ${ }^{61}$ The Rome Treaty contains provisions whose aim or effect is to guarantee or improve the position of the individual in the Community. ${ }^{62}$ On the basis of some of these provisions, the European Court of Justice at Luxembourg has given some important judgments regarding the protection of fundamental rights. ${ }^{63}$ The role of the Luxembourg Court is crucial because it is in effect a judicial organ of each member state. Its strongly unifying federal approach has increasingly resembled the philosophy of the United States Supreme Court from Marbury v. Madison ${ }^{64}$ onwards.

Some provisions of the Rome Treaty are directly applicable in member countries and have supremacy over all other

${ }^{61}$ The Community system rests on the original consent, and ultimately on the continuing consent, of member states and hence of national Parliaments. The English and Scottish legal systems will remain intact. Certain provisions of the treaties and instruments made under them, concerned with economic, commercial and closely related matters, will be included in our law. The common law will remain the basis of our legal system, and our courts will continue to operate as they do at present. In certain cases however they would need to refer points of Community law to the European Court of Justice. All the essential features of our law will remain, including the safeguards for individual freedom such as trial by jury and habeas corpus and the principle that a man is innocent until proved guilty, as well as the law of contract and tort (and its Scottish equivalent), the law of landlord and tenant, family law, nationality law and land law.

The United Kingdom and the European Communities, Cmnd. No. 4715, at If 31 (1971). This statement does not recognise the potential impact of European Community law in creating greater protection for the basic rights and freedoms of United Kingdom (together with other E.E.C.) nationals and in developing a European system of constitutional or public law. Admittedly, the jurisprudence of the Luxembourg Court was less well developed in this field in 1971 than thereafter; but the provisions of the Rome Treaty itself and several decisions of the Court indicated the shape of things to come.

${ }^{62}$ See, e.g., Bulletin of the European Communities, The Protection of Fun-

Damental Rights In the European Community (Supp. May, 1976).

${ }^{6}$ Id. See also P. Pescatore, La Protection des Droits Fondamentaux par le

Pouvoir Judiciaire, Report for the Seventh Congress of the International

FEDERATION For EUROPEAN LAW (Brussels 1975).

${ }^{64} 5$ U.S. (1 Cranch) 137 (1803). 
internal laws. For example, earlier this year, the Luxembourg Court decided ${ }^{65}$ that the principle of "equal pay for equal work" is self-executing and therefore confers on individuals rights enforceable before the national courts, particularly with regard to those types of sex discrimination that arise directly from legislative provisions or collective labour agreements, as well as those types in which men and women receive unequal pay for equal work.

The implications of this decision for the country that venerates the doctrine of absolute Parliamentary sovereignty are mind boggling. As from the date of the Luxembourg Court's judgment, a new cause of action has been created in United Kingdom law. An individual may invoke the Rome Treaty in our courts to obtain equal pay without discrimination based on sex. If the existing British equal pay and sex discrimination statutes do not give as extensive redress as the Rome Treaty, the individual will be entitled to the more extensive protection of the latter. To that extent, the Acts of the Westminster Parliament will have been amended or displaced by the judgment of the Luxembourg Court as applied by United Kingdom courts. The implications might even be mind boggling in similar circumstances in the United States. It is as though the substance of the proposed Equal Rights Amendment were to become an enforceable part of American domestic law, not through ratification of an amendment to the Constitution, but by virtue of a judgment of the International Court of Justice interpreting a human rights treaty to which the United States was a party.

In short, the individual already enjoys some fundamental rights in the United Kingdom, indirectly through the European Convention, and directly through the Rome Treaty. And, in light of these developments, it seems to me to be inevitable that the constitutional framework, the administrative law, and the judicial process of the United Kingdom will be radically transformed by the European dimension.

\section{Conclusion}

Mr. Roy Jenkins, who will soon be the President of the Commission of the European Communities, has recently observed that

${ }^{65}$ Defrenne v. Societé Anonyme Belge de Navigation Aerienne (SABENA), [1976] 2 Comm. Mkt. L.R. 98, 2 Coмm. Mкr. REP. (CCH) ๆ 8346. 
It is a measure of the difference in existing practice between ourselves and most other countries that the two great federations of North America probably have more in common in these respects with our neighbours in continental Western Europe than with us in Britain -despite the ties of the English Language and the Common Law. ${ }^{66}$

I believe that this difference will greatly diminish. And I hope that long before 1989-the year of the Bicentennial of the French Declaration of the Rights of Man and of the coming into force of the United States Constitution-fundamental rights will be enforceable in United Kingdom courts under a written constitution forming the paramount law of the nation, in harmony with the paramount law of the new community of Europe.

${ }^{66} 73$ Guardian GazetTe 774 (1976). 